\title{
The Contribution of the Social Enterprise Sector to the UK Economy
}

\author{
Sally Kah \\ Liverpool John Moores University, UK
}

\begin{abstract}
Social enterprises (SEs) contribute significantly to the UK economy. Yet, their collective contributions are a hidden feat. This paper presents the development, scale and scope of these enterprises, followed by a guide to inform opportunities for future research. This study is important because it presents a critical insight into the contribution of SEs from a market with the world's first largest social investment wholesaler. This insight will improve systems and models designed to improve operations and performance of these organisations. This study adopts qualitative document analysis of secondary data, namely 'The Future of Business: State of Social Enterprise Survey' (2017), 'Social Enterprise UK Impact Report' (2018), 'Northern Ireland Third Sector Report' (2013), 'Mapping the social business sector in Wales' (2017) and 'Social Enterprise Scotland' (2017). Documents were analysed using the Nvivo software, through a content analysis approach. This study found that SEs have three forms of contributions: social, economic and environmental. Meanwhile, the areas that emerged for future research are diversity and inclusion, localism, financial performance, service-led sector, employment opportunities, waste management and environmental policies. Due to the nature of the secondary data used, the findings may not be generalisable for all regions. Therefore, future research should employ primary data while utilising a sufficiently large sample to capture the key events in the sector. This paper provides pertinent information for research bodies and policy makers who are interested in funding research in SEs and/or sustainable development studies, while providing novel insights into key areas of contributions: social, economic and environmental domains. Finally, the themes for future direction adds value to the conceptualisation of the SE sector.
\end{abstract}

Keywords: Social enterprise, Social economy, UK

DOI: $10.7176 / \mathrm{EJBM} / 11-20-03$

Publication date:July $31^{\text {st }} 2019$

\section{Introduction}

It is widely stipulated that the financial crisis of 2008 and the austerity measures imposed by the subsequent UK governments have resulted in increasing levels of unemployed and underemployed people. This has presented both a challenge and opportunity for social enterprises (SEs) in the UK. In addition to the operational and impact challenges, there is growing interest in understanding the scale and scope of their activities on the economy. A government report on the state of SE in 2017 revealed 471,000 such enterprises, employing 1.4 million people (Department for Business, Energy and Industrial Strategy, 2017). In contrast, Social Enterprise UK ([SEUK], 2015) claimed that there are 100,000 SEs contributing £60 billion to the UK economy and employing 2 million people. Such disparity adds to the challenge of conceptualising the sector.

Participation in SE activities has increased over time. For instance, Scotland's Festival of Social Enterprise witnessed a 150 percent increase in public participation at their 2018 event, where the growth rate of brands identified as responsible was double that of mainstream brands (Burley, 2018). There are many publications focused on the SE sector that provide diverse information regarding its development, scope, scale and size. However, there is a paucity of publications on how SEs foster economic growth in the four regions of the UK, namely England, Scotland, Northern Ireland and Wales. Therefore, this paper examines the scale, scope and scale of SEs to provide in-depth insight into the social, economic and environmental contributions. The research questions for this study are as follows: What are the contributions of the UK's SEs? What are the specific social, economic and environmental contributions? This paper maps the social, economic and environmental contributions, where the themes developed for each criterion will then form a framework to inform future research.

The subsequent sections present a critical analysis of the UK's SE sector. The first section includes the historical development of SEs, while the second section provides a concise review of the literature on the characteristics and legal structures. The third section offers insight into the scale and scope of the sector, and is followed by the methodology, findings and discussion. The paper then presents a framework of the social, economic and environmental contributions of the sector, before the conclusion and direction for future research.

\subsection{Historical development of SE}

The UK's SE sector can be traced back to the Rochdale co-operative movement of 1844 (see Drayton, 2002; Haugh, 2006; Ridley-Duff and Bull, 2011), where the exploitative working conditions of factory workers led to the social movement that marked the emergence of SEs (The Institute for Social Entrepreneurs, 2008). By the 1930s, global economic crises had become an indicator of the social and economic impasse that contributed to the 
development of social organisations (Albers and Uebele, 2015). The development of non-profit social organisations in Europe in the 1950s is a noticeable post-Second World War development (Nyssens, 2009), since many European countries, including the UK, experienced social and economic deprivation (Doeringer, 2010). In fact, 40 percent of people in post-war Europe were classified as long-term unemployed (Doeringer, 2010). At the time, SEs adopted non-profit logic to tackle the poverty and housing problems prevailing in the UK (Nyssens, 2009).

The Freer Spreckley publication in 1981 is akin to the development of SEs in the UK (Ridley-Duff and Bull, 2011). Although the training manual was devised for SEs, it described a process for co-operatives to prove their impact on social, economic and environmental criteria (Bull, 2015). By the 1990s, there was a surge in the sector with more organisations - for-profit and not-for-profit SEs-working together for social change (SEUK, 2014). During this period, SEs gained policy recognition under the Labour government in 1997 (Teasdale, 2012; Bull, 2015), which proposed interventions and emphasised the need for greater accountability to the public, referred to by Giddens (2000) as the third way.

By 1998, educational institutions such as the School for Social Entrepreneurs had been developed to inspire individuals to start up organisations for social and environmental change (School for Social Entrepreneurs, 2018). This institution provides opportunities for new social entrepreneurs across the UK with the support of Lloyds Bank and the Bank of Scotland. In 2002, Social Enterprise UK was established to represent a national voice for SEs in the UK. This coalition body for the UK's SEs is a strategic partner to six government departments and leads on public SE policy (SEUK, 2017). In the same year, the UK's Department for Trade and Investment ([DTI], 2002) published a definition of SE, which is widely cited in the UK literature (see Ridley-Duff, 2009; Buckingham et al., 2010; Doherty et al., 2014). As seen in section 2 below, the definitions of SE are a contested concept whose meaning is historically, culturally, politically and geographically variable (Kerlin, 2009; Teasdale, 2012). Notwithstanding, the government's definition fails to infer democratic control to the scope of the solutions (RidleyDuff and Bull, 2016).

The government has continued to increase support for the third sector through its engagement with the national body for the sector. For this reason, the UK is considered the most developed institutional support structure for SE internationally (Nicholls, 2010). Significant growth was observed in SEs since 2003, suggesting that the government policy and strategic engagement with the sector was successful (Nicholls, 2010). In 2005, the Community Interest Company (CIC) legal structure was established under the Companies Act, 2004, for those SEs who wish to reinvest their profits into the business. However, the structure was criticised for the paucity of profit reinvested (Third Sector, 2015).

By 2009, the UK sought to expand its social change internationally, with the British Council launching the Social Enterprise Programme to create opportunities between the UK and China, supporting aspiring social entrepreneurs with skills, training, mentoring and access to experts from the UK's SE sector. Over 3,000 social entrepreneurs have been trained and the initiative received $£ 3.7$ million in pledges for 117 SEs (British Council, 2015). This programme represents a government strategy to strengthen its role in developing the sector through knowledge exchange and capacity building. However, the government should consider the geographical and cultural landscape of SEs in both countries to ensure effective mentorship.

For recognition and credibility, an accreditation standard was introduced in 2010 under the Social Enterprise Mark (SEM), despite the conceptual and practical challenges (Ridley-Duff and Southcombe, 2012). The purpose of the SEM is to defend government-funded institutions from the brand identity (Finlay, 2011), with the SEM preventing private corporations from claiming they are SEs (Ridley-Duff and Southcombe, 2012). Interestingly, the Social Value Act came into force in 2013, and requires those who authorise public services to consider how they can secure social, economic and environmental benefits. This Act is dovetails with the government's definition of SEs. Therefore, the agenda for SEs is developing to meet the primary objectives established by the government and strategic collaborators such as Social Enterprise UK. Figure 1 below illustrates the aforementioned historical developments. 


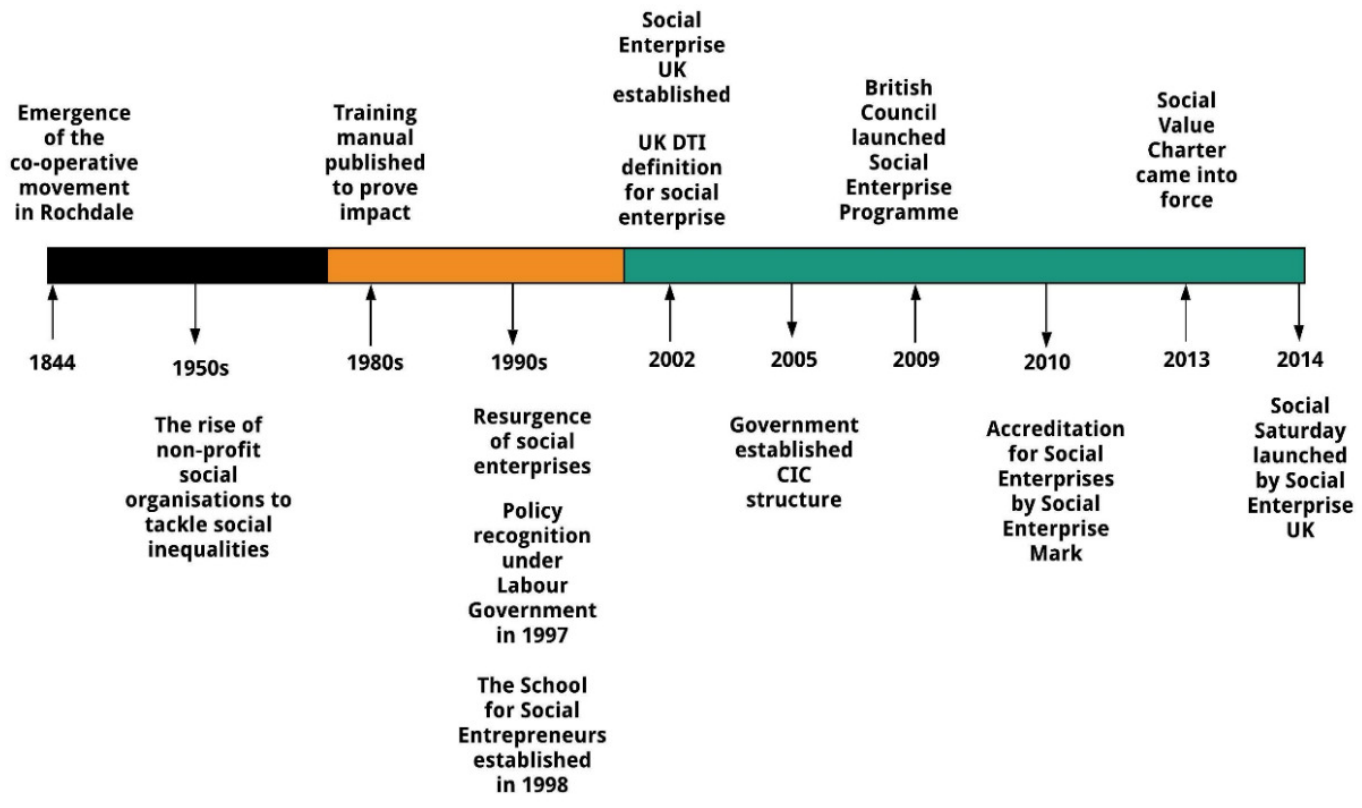

Figure 1. Development of the UK's SE sector

\section{Literature Review}

\subsection{Social enterprise: Characteristics and legal structures}

The UK government defined the SE as "a business with primarily social objectives whose surpluses are principally reinvested for that purpose in the business or in the community, rather than driven by the need to maximise profit for shareholders and owners" (DTI, 2002, cited in Department for Business Innovation and Skills, 2011, p.2). However, there are conceptual and theoretical differences in the definition of SE. Existing research (Nicholls, 2010; Choi and Majumdar, 2014) argued that the definition of SE is challenged due to the lack of uniformity. However, the current study contests this notion by presenting a succinct definition of SE developed by Santos (2012), who described SE as a distinctive domain that addresses neglected problems with positive externalities in a manner that such externalities are internalised for the creation of positive social change. It can be argued that the varying characteristics of SEs in different contexts influence the discourse concerning this sector. Salamon et al.'s (2004) comparative data on SE in non-profit organisations found that for 34 countries, on average 53 percent of their revenue was acquired from trading services.

The paper presents the definitions and characteristics of SE (see Table 1). The cumulative view of social and financial techniques intended for social change is relevant to Doherty et al.'s (2014) hybridity as the defining characteristics of SEs. Urban and Kujinga (2017) claimed that SEs focus on tangible outcomes, while Hieu (2017) found that SEs have communication that is more open, feature less rigorous management control and are marketoriented organisations. In contrast, Selloni and Corubolo (2017) argued that many SEs are too centralised with a high degree of bureaucratisation (top-down approach).

Table 1. Definitions and characteristics of SE

\begin{tabular}{|l|l|l|}
\hline & Definition of SE & $\begin{array}{l}\text { Characteristics of } \\
\text { SE }\end{array}$ \\
\hline Dart (2004) & Adopts business as an instrument for social development. & Social change \\
\hline $\begin{array}{l}\text { Barraket et al. } \\
(2017)\end{array}$ & $\begin{array}{l}\text { An organisation that exists for a social mission and engages in trading to } \\
\text { meet its mission, using commercial techniques to achieve social ends. }\end{array}$ & $\begin{array}{l}\text { Commercial } \\
\text { techniques } \\
\text { Social mission }\end{array}$ \\
\hline Santos (2012) & $\begin{array}{l}\text { An organisation that trades. It is not-for private benefit, which creates a } \\
\text { positive social and environmental impact. }\end{array}$ & $\begin{array}{l}\text { Social impact } \\
\text { Commercial } \\
\text { techniques }\end{array}$ \\
\hline $\begin{array}{l}\text { Doherty et al. } \\
(2014)\end{array}$ & $\begin{array}{l}\text { Hybrid organisations that use the dual mission of financial sustainability } \\
\text { and social mission }\end{array}$ & $\begin{array}{l}\text { Financial } \\
\text { sustainability } \\
\text { Social mission }\end{array}$ \\
\hline
\end{tabular}

Creating social goals is the primary focus of SEs. The above definitions not only demonstrate the complexity of social organisations, but they also prove that the fundamental tenets of these organisations differ from 
commercial enterprises, in that social issues are central to their development (see Spreckley, 1981; DTI 2002; Alter, 2007; Yunus, 2007). SEs solve these issues through the application of entrepreneurialism, financial sustainability models and collective action. Interestingly, community ownership and control are vital to the structure and management of such organisations. Meanwhile, there are other characteristics that distinguish SEs from for-profit businesses, where the former's activities are distinct in the sense that they create opportunities to tackle social and environmental issues through the creation of social purpose organisations (Haugh, 2005), while they innovatively address sustainability issues (Nicholls, 2006). There are different types of SEs in the UK, including fair trade, community enterprises, social firms, credit unions, co-operatives, development trusts, public sector spinouts and the trading arms of charities (SEUK, 2017). These organisations are located in the third sector, which is also known as the social economy (Pearce, 2003). More recently, legitimacy has been noted as a critical facet of the organisations, where social investors, policy-makers and the government are key drivers of the social impact (Ebrahim and Rangan, 2014; Arena et al., 2015) to demonstrate legitimacy.

Similar to traditional enterprises, SEs can operate under any legal structure (DLA Piper, 2014), with the legal structure or constitution enabling SEs to operate in a framework related to their objectives and the rules that govern them (Snaith, 2007). Globalisation and the liberalisation of trade persuaded SEs to re-examine their legal structures (Peattie and Morley, 2008). Mswaka and Aluko (2014) explored the influence of legal structures on the outcome of SEs, and classified the legal structures into three groups: Class A (Company Limited by Guarantee and Industrial Provident Society [IPS]), Class B (CIC) and Class C (Company Limited by Shares [CLS]). Although this study does not examine all the legal structures adopted by SEs, the broad range of legal structures used by such enterprises can be found in DLA Piper and UnLtd (2014). While SEs can adopt any legal structure such as sole proprietorship and partnership, they select specific structures in relation to their goals. The CIC is specifically designed for SEs, with over 13,000 registered and an average of 1,000 established each year since its introduction in 2005 (SEUK. 2017).

\subsection{The scale and scope of SE}

The growth of the sector is evident in the scale of activities and contribution to the economy. SEs play a significant role in the economy (Mason, 2010), operating in a wide range of industries and sectors. The scale of operation in this sector is proven by their financial performance due to innovative products and services, with a SEUK (2015) report finding that 6 percent of SEs have a turnover of $£ 5$ million, 10 percent have a turnover of up to $£ 5$ million, and 20 percent have a turnover of up to $£ 1$ million per year.

There are differences in the scale and scope of SEs across the four regions of the UK: England (84\%), Scotland (7\%), Wales (5\%) and Northern Ireland (3\%) (SEUK, 2015). Unsurprisingly, the number of SEs and growth level differ. This section explores the scale and scope of this sector in the UK economy. In this paper, scale is used to describe the type of sector the organisations operate in (Ekpenyong and Nyong, 1992). There are three scale criteria: economic sector, economic activity and economic contribution. On the other hand, scope implies the location of these organisations. While this paper acknowledges that there are other contributions in the sector (i.e. diversity, product development and so on), the aim is to present concise information on the scale and scope of the activities in this sector. Table 2 below outlines the scale of this sector in the UK economy. 
Table 2. The scale of SEs across the four regions of the UK

\begin{tabular}{|c|c|c|c|c|}
\hline \multirow{2}{*}{ Region } & \multirow{2}{*}{$\begin{array}{l}\text { No. of } \\
\text { SEs }\end{array}$} & \multicolumn{3}{|c|}{ Scale } \\
\hline & & Economic sector & Economic activity & Economic contribution \\
\hline England & $92,229^{8}$ & $\begin{array}{ll}\text { - } & \text { Business support } \\
\text { and consultancy } \\
\text { - } & \text { Education } \\
\text { - } & \text { Retail } \\
\text { - } & \text { Creative } \\
& \text { industries } \\
\text { - } & \text { Employment and } \\
& \text { skills }\end{array}$ & $\begin{array}{l}52 \text { percent increased } \\
\text { their turnover in the past } \\
12 \text { months }{ }^{1} \\
65 \text { projects are } \\
\text { delivering around } £ 1 \\
\text { billion of public } \\
\text { services }^{2}\end{array}$ & $\begin{array}{l}\text { - } 41 \text { percent created jobs } \\
\text { in the past } 12 \text { months }{ }^{1} \\
\text { - } 50 \text { percent reported a } \\
\text { profit, with } 26 \text { percent } \\
\text { breaking even }^{1}\end{array}$ \\
\hline Scotland & $5,600^{5}$ & 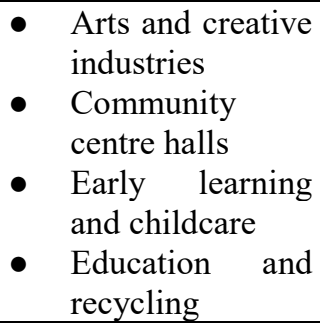 & $\begin{array}{l}\text { - } 61 \text { percent generate } \\
\text { income from trading }{ }^{3} \\
\text { - } 79 \text { percent earn income } \\
\text { from the general public }{ }^{3}\end{array}$ & $\begin{array}{l}\text { - } £ 2 \text { billion gross value } \\
\text { - } \text { added }^{3} \\
£ 3 \text { billion total annual } \\
\text { income } \\
\text { - Net worth is } £ 5 \text { billion }{ }^{5} \\
\text { - } 100,000 \text { people in } \\
\text { employment }^{3}\end{array}$ \\
\hline Wales & $1,698^{4}$ & $\begin{array}{ll}- & \text { Culture } \\
\text { - } & \text { Leisure } \\
\text { - } & \text { Education } \\
\text { - } & \text { Environment } \\
\end{array}$ & $\begin{array}{l}66 \text { percent earn income } \\
\text { from trading }{ }^{4} \\
\text { - } 57 \text { percent earn income } \\
\text { from the general public }{ }^{2}\end{array}$ & $\begin{array}{ll} & £ 2.37 \text { billion turnover } \\
\text { - } & 40,800 \text { jobs created }^{2}\end{array}$ \\
\hline $\begin{array}{l}\text { Northern } \\
\text { Ireland }\end{array}$ & $473^{6}$ & $\begin{array}{l}\text { - Community } \\
\text { development } \\
\text { - Education and } \\
\text { training } \\
\text { - The arts }\end{array}$ & $\begin{array}{l}\text { - } 68 \text { percent reported a } \\
\text { profit/surplus in } \\
2010 / 11^{6} \\
32 \text { percent reported a } \\
\text { turnover of between } \\
£ 499,999 \text { and } £ 1 \text { million }\end{array}$ & $\begin{array}{l}\text { The sector is worth } £ 625 \\
\text { million }{ }^{7} \\
\text { Over } 12,000 \text { employed, } \\
\text { plus } 13,000 \text { volunteers } \\
\text { - Supports } 24,860 \text { jobs, } \\
\text { and achieves } £ 581 \\
\text { million in wages } \\
\text { annually }^{7}\end{array}$ \\
\hline
\end{tabular}

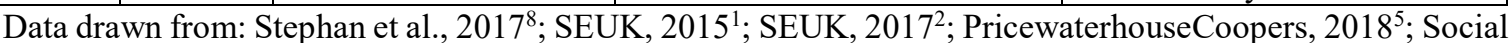
Value Lab, 2017³; Allies and Irving, 2017 ; PricewaterhouseCoopers, 2013 ; Strategem, $2019^{7}$.

Similarly, the scope of the sector differs between regions. Of all the SEs in the UK, 44 percent operate in England, whilst 24 percent are located in Northern Ireland (SEUK, 2017). Meanwhile, 34 percent of all SEs in Scotland are located in rural areas. Wales presents a different structure, with 63 percent of SEs operating across one (local authority), whilst 11 percent serve the rest of the region (SEUK, 2015).

Although SEs provide benefits to communities and the economy, there are challenges in the sector. For example, the increasing pressure to demonstrate the social impact, difficulties in accessing finance and the decline in grant funding are barriers for SEs in Scotland and Wales. Interestingly, 12 percent of SEs in Wales identified Brexit as a barrier, along with the lack of marketing skills and public awareness (SEUK, 2017). Furthermore, in an investigation exploring the barriers to SE growth, Davies et al. (2018) found value differences, institutional norms and business models as barriers for SEs.

Based on the scale and scope of activities in the sector, the present author categorises the contributions of the sector into three domains: social, economic and environmental. These categories are both reflected in the definitions of SEs, and the rationale for developing such an enterprise (Faruk et al., 2017). Social contributions represent the rational outcomes created by SEs (El Ebrashi, 2013). Economic contributions are the monetary value created because of social activities (Peattie and Morley, 2008). Environmental contributions reflect the impact on natural conservation (McLoughlin et al., 2009).

\section{Methodology}

\subsection{Data collection and analysis}

This study adopted a qualitative methodology employing secondary data, with the main method of data collection being document analysis. Whilst documents have been commonly utilised as a means of triangulating other methods (Denzin, 1970), Merriam (1988) asserted that "documents of all types can help the researcher uncover meaning, develop understanding, and discover insights relevant to the research problem" (p. 118). Meanwhile, Bowen (2009) argued that documents can be used as a stand-alone method, as applied in Wild et al.'s (2009) study on engineers' information needs and document usage. The use of document analysis is crucial to this study because it provides insights into the contributions of SEs, while uncovering themes that need to be investigated (Bowen, 
2009).

Three steps were involved in the process of data collection and analysis. First, documents were selected for review. A search for documents on government databases, the Social Enterprise UK website and academic databases using the search terms 'social enterprise contributions', 'UK social enterprise sector' and 'social enterprise economy' led to the retrieval of a total of 31 documents. Each document was read carefully to ensure that they did not contain duplicate information, and that the information reflected each region of the UK. Following this process, 6 documents were selected as providing the contributions of SEs to the four regions of the UK economy. The documents used in this study are presented below in Table 3.

Table 3. Documents selected and the data analysed

\begin{tabular}{|l|l|}
\hline Documents selected & Data analysed \\
\hline $\begin{array}{l}\text { The Future of Business - State of Social Enterprise Survey (SEUK, } \\
\text { Social Enterprise UK Impact Report 2017/2018 (SEUK, 2018) }\end{array}$ & $\begin{array}{l}\text { Positive or negative change created } \\
\text { from social projects }\end{array}$ \\
\hline $\begin{array}{l}\text { A survey of Northern Ireland's third sector and its potential to become } \\
\text { more enterprise driven (PwC, 2013) }\end{array}$ & $\begin{array}{l}\text { Social, economic and environmental } \\
\text { contributions }\end{array}$ \\
\hline $\begin{array}{l}\text { Mapping the social business sector in Wales (Social Business Wales, } \\
\text { 2017) }\end{array}$ & SEs and their contributions \\
\hline Enterprise in Scotland: Census 2017 (Social Value Lab, 2017) & Social contributions and related data \\
\hline $\begin{array}{l}\text { Longitudinal Small Business Survey 2017: SME employers } \\
\text { (Department for Business, Energy \& Industrial Strategy) }\end{array}$ & SEs in the UK \\
\hline
\end{tabular}

The second stage involved verifying the credibility of the documents. Scott (1990, cited in Mogalakwe, 2006, p.6) reported on the quality criteria to be applied for document review. These criteria are authenticity, credibility, representativeness and meaning. Authenticity checks for evidence that the document is genuine and of reliable origin, and therefore the author verified the authorship of the documents; for example, Social Enterprise UK is the national body for SEs in the UK, while PricewaterhouseCoopers is a multinational professional services network. Credibility is concerned with ensuring error-free evidence. In this study, all documents comprise existing data published on government databases, Social Enterprise UK website and PricewaterhouseCoopers. Representativeness checks whether the evidence is typical of its kind, and if not, to what extent its atypicality is known. Since this study utilises reports that describe the contributions of SEs in the UK, the author read the introduction of each report to ensure that the content was representative of the research purpose. Finally, meaning examines whether the evidence is clear and comprehensible. As per representativeness, reading the introductions allowed the author to assess the literal meaning of each report as a whole.

The third stage involved coding the content into themes (Bowen, 2009). All documents were analysed using the Nvivo software, with a text search for 'social', 'economic' and 'environmental factors' examined to demonstrate the robustness of the coding process. The fourth stage entailed the content analysis of the data, which was effective in this study because such analysis systematically transforms large documents into highly organised and concise summaries (Erlingsson and Brysiewicz, 2017). The data analysed for content analysis can be found in Table 3 above.

For quality and consistency, the author applied Erlingsson and Brysiewicz's (2017) process to content analysis, reading and re-reading each document carefully to fully comprehend the contributions of SEs to the UK economy. Each document was analysed separately to avoid any misrepresentation of the data. Then, the contributions were condensed into codes. After this, the condensed codes for each report were processed in a Microsoft Word document, followed by the grouping of the codes. Since the purpose of the study was to capture the contributions of SEs, the codes were grouped under three criteria: social, economic and environmental contributions. The codes for each criterion were further examined to create themes, where the purpose of creating themes for the codes was to communicate the underlying meaning of the contributions (Bowen, 2009). The next section presents the findings of the analysis.

\section{Findings and Discussion}

This study found that SEs are hybrid institutions that contribute to the triple bottom line: social, economic and environmental contributions. Figure 2 below presents common codes drawn from the document analysis for all regions. Based on these codes, themes were drawn for future research. The main contributions for social are diversity and inclusion, and localism; for the economic contributions are financial performance, service-led sector, and employment opportunities; while waste management and environmental policies are the themes associated with the environmental contributions.

All regions demonstrate inclusive social structures that reflect the diversity of their locality. For instance, 79 percent recruit over half of their staff locally (SEUK, 2017, 2018). Diversity was noted in the number of minority groups: 34 percent have Black Asian Minority Ethnic representation and 36 percent have a director with a disability. 
Furthermore, these organisations demonstrate a clear contribution to the current discourse of women in leadership; for example, in the Social Enterprise UK (2018) report it was revealed that women lead 49 percent of SEs.

Interestingly, all regions adopt multiple income streams to meet their social, economic and environmental goals. Retail and services are the largest operating sectors; however, the public sector is the main source of income for many (i.e. England, Scotland and Wales) due to procurements and social investment funds. The economic contributions are tailored to the development of local economies, profitability and the Social Value Act (2012). This Act is influential in terms of the assessment of the social, economic and environmental well-being of SEs in all regions, enabling the organisations to reinvest their profit into local economies, minimise environmental impact and rebuild deprived communities.

Sustainable business has been a critical aspect of SE development; this is evident in their strategy to address environmental issues, where the document analysis revealed a significant number of SEs (92\%) using their profit to further environmental and social goals. Moreover, 85 percent indicated that their organisation actively aims to minimise environmental impact. Policies were developed to support environmental goals such as low energy usage, a walk-to-work policy and drinking tap water. Waste management is a common theme because of the environmental objectives of many SEs (see Table 2 for the top sectors in Scotland and Wales). This objective is reflective of the current rhetoric on environmental management in the UK, and in particular, recycling. Recycling and other waste recovery are considered the most common final waste treatment type in the UK (Department for Environment, Food and Rural Affairs, 2019). Therefore, SEs are catalysts in the environmental management of waste from both businesses and households.

Unlike traditional enterprises, SEs are accountable to their communities, more environmentally conscious and create both innovative products and services. The hybrid nature identified in this study supports Doherty et al.'s (2014) notion of the hybridity of the SE as its defining characteristic. Interestingly, however, multiple income streams are utilised to develop innovative social interventions, although this could be anticipated since from the documents analysed, the majority of SEs identified the lack of funding as a barrier to their growth. An investigation by Davies et al. (2018) echoed the concept of local and industry anchoring for future research. Similarly, recent research explored government failure and resource scarcity suggests (Saebi et al., 2019) that impedes SE growth.

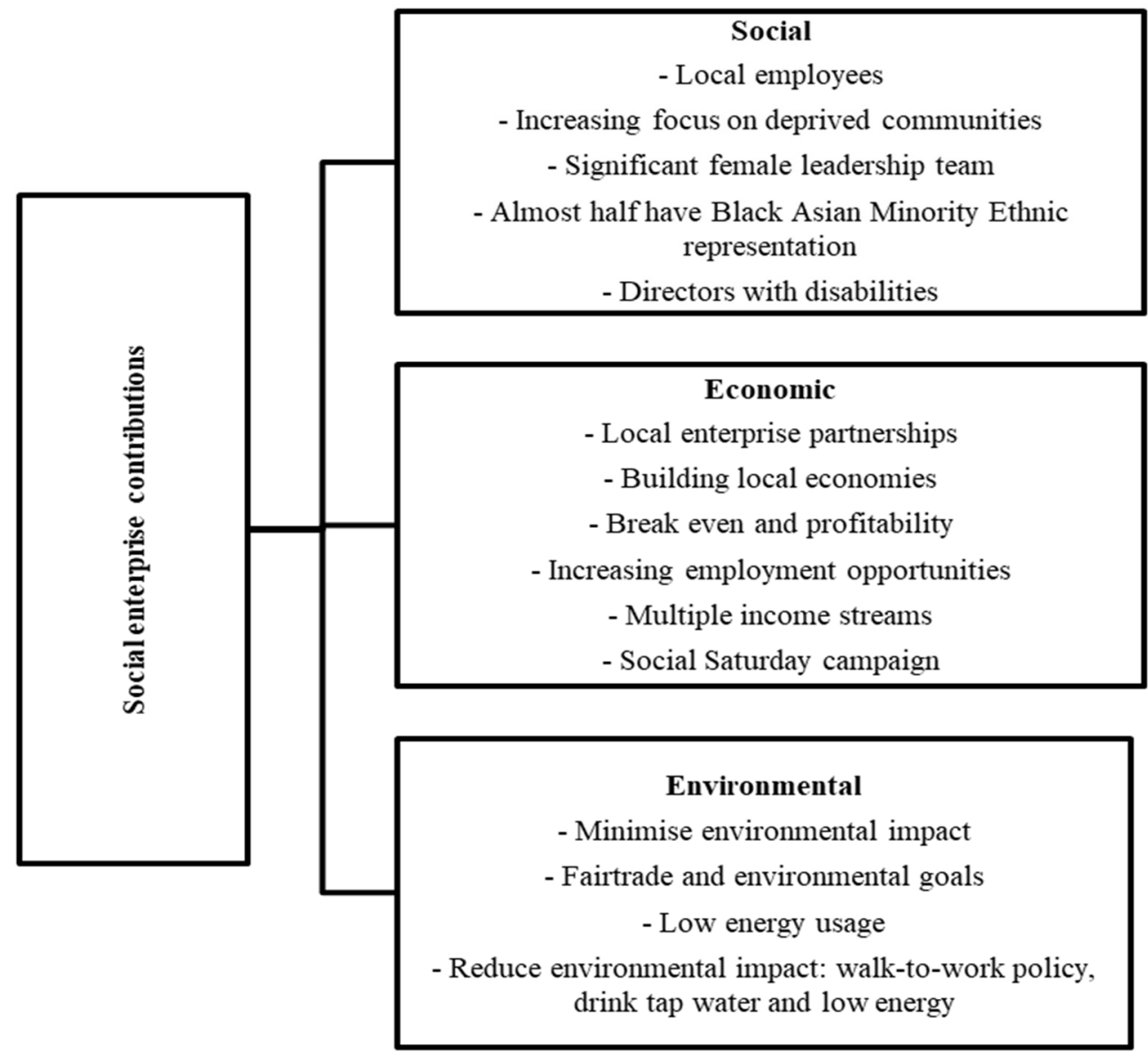

Figure 2. Framework describing the key contributions from UK SEs 


\section{Conclusion}

This study examined the contributions of SEs to the UK economy based on three criteria: their social, economic and environmental contributions. The study found that while SEs exist in all four regions of the UK (i.e. England, Scotland, Wales and Northern Ireland), the scope differs for each region in terms of the number of SEs and the operating sectors. Nonetheless, they all adopt multiple income streams to meet their social goals. SEs in the UK contribute to the diversity of local communities, create employment opportunities and develop policies to minimise environmental waste. However, they face challenges such as access to funding, the lack of marketing skills and public awareness, and Brexit.

This study recommends that primary research be conducted on the key themes identified in Figure 3 below. Further research should consider a broader sample of social enterprise (fairtrade, BCorp, co-operatives and voluntary organisations). Furthermore, the economic sector (see Table 2) should be investigated for contextual intelligence. These recommendations points towards an analytical approach to understanding the model of SE. The author acknowledges that there are extant studies on SE and the sustainable model, which support environment goals. However, further research is required to capture the extent of these themes on the growth of SEs, both in the UK and more broadly in the international domain.

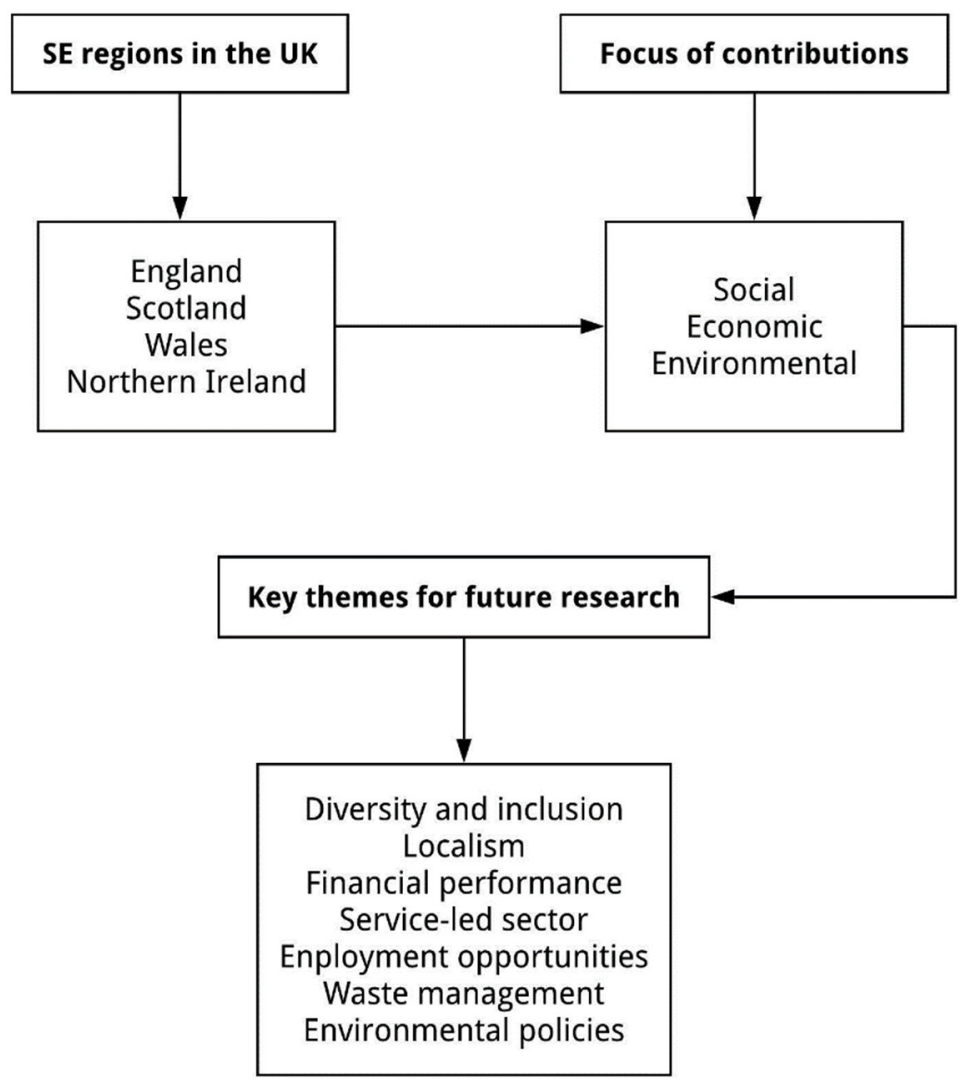

Figure 3. Recommendations for future research in SE

\section{References}

Albers, T., \& Uebele, M. (2015). The global impact of the great depression. Economic History Working Paper No 218. London: The London School of Economics and Political Science.

Allies, O. \& Irving, J. (2017). Mapping the social business sector in Wales. Social Business Wales. [Online] https://sewfonline.com/wp-content/uploads/2017/07/Social-Business-Mapping-Report-28FINAL292017.pdf [Accessed 10th November, 2018].

Alter, K. (2007). Social enterprise typology. Virtue Ventures LLC.

Arena, M., Azzone, G., \& Bengo, I. (2015). Performance measurement for social enterprises. Voluntas, 26, 649672.

Barraket, J., Douglas, H., Eversole, R., Mason, C., McNeill, J., Morgan, B. (2017). Classifying social enterprise models in Australia. Social Enterprise Journal, 13(4), 345-361.

Bowen, G. A. (2009). Document analysis as a qualitative research method. Qualitative Research Journal, 9(2), 27-40.

British Council. (2015). Report: Social enterprise in the UK. [Online] Available at: 
https://www.britishcouncil.org/society/social-enterprise/news-events/news-social-enterprise-in-the-uk [Accessed: $21^{\text {st }}$ December, 2018].

Buckingham, H., Pinch, S., \& Sunley, P. (2010). The regional geography of social enterprise in the UK: a review of recent surveys. Third Sector Research Centre. Working Paper 35. Birmingham: University of Birmingham.

Bull, M. (2015). Shape sorting: Towards defining social enterprise in the UK in social, environmental and ethical enterprise. Proceedings of ISBE Conference. 11-12 November 2015. Glasgow.

Burley, H. (2018). Thousands of visitors expected at social enterprise festival. [Online] Available at: https:/www.scotsman.com/business/companies/thousands-of-visitors-expected-at-social-enterprise-festival1-4773762 [Accessed: $21^{\text {st }}$ January, 2019].

Choi, N. \& Majumdar, S. (2014). Social entrepreneurship as an essentially contested concept: Opening a new avenue for systematic future research. Journal of Business Venturing, 29, 363-376.

Dart, R. (2004). The legitimacy of social enterprise. Nonprofit Management and Leadership, 14, 411-424.

Davies, I. A., Haugh, H., \& Chambers, L. (2018). Barriers to social enterprise growth. Journal of Small Business Management, 00(00), 1-21.

Denzin, N. K. (1970). The research act: A theoretical introduction to sociological methods. New York, NY: Aldine.

Department for Business, Energy and Industrial Strategy. (2017). Social enterprise: Market trends 2017. [Online] Available

https://assets.publishing.service.gov.uk/government/uploads/system/uploads/attachment_data/file/644266/ MarketTrends2017report_final_sept2017.pdf [Accessed: 22 ${ }^{\text {nd }}$ January, 2019].

Department for Trade and Industry. (2002). Social enterprise: A strategy for success. London: Department for Trade and Industry.

Department for Business, Innovation and Skills. (2011). A guide to legal forms of social enterprise. [Online] Available https://assets.publishing.service.gov.uk/government/uploads/system/uploads/attachment_data/file/31677/11 -1400-guide-legal-forms-for-social-enterprise.pdf [Accessed $22^{\text {nd }}$ April, 2019].

Department for Environment, Food \& Rural Affairs. (2019). UK statistics on waste. Government Statistical Service. [Online] Available

at: https://assets.publishing.service.gov.uk/government/uploads/system/uploads/attachment_data/file/784263/U K Statistics on Waste statistical notice March 2019 rev FINAL.pdf [Accessed: $23^{\text {rd }}$ May, 2019).

DLA Piper and UnLtd. (2014). Structures for social enterprises. [Online] Available at: https://unltd.org.uk/portfolio/3-7-determining-the-right-legal-structure-for-your-social-enterprise/ [Accessed: $15^{\text {th }}$ November, 2018).

Doeringer, M. F. (2010). Fostering social enterprise: a historical and international analysis. Duke Journal of Comparative and International Law, 20(2), 291-329.

Doherty, B., Haugh, H., \& Lyon, F. (2014). Social enterprises as hybrid organisations: A review and research agenda. International Journal of Management Reviews, 16(4), 417-436.

Drayton, W. (2002). The citizen sector: Becoming as entrepreneurial and competitive as a business. California Management Review, 44(3), 120-133.

Ebrahim, A. \& Rangan, V. K. (2014). What impact? A framework for measuring the scale and scope of social performance. California Management Review, 56 (3), 118-141.

Ekpenyong, D. B. \& Nyong, M. O. (1992). Small and medium-scale enterprises in Nigeria: Their characteristics, problems and sources of income. AERC Research Paper 16. Nairobi: African Economic Research Consortium.

El Ebrashi, R. (2013). Social entrepreneurship theory and sustainable social impact. Social Responsibility Journal, 9(2), 188-209.

Erlingsson, C. \& Brysiewicz, P. (2017). A hands-on guide to doing content analysis. African Journal of Emergency Medicine, 7(3), 93-99.

Faruk, M. O., Hassan, N., \& Islam, N. (2017). Factors influencing the development of social entrepreneurship in Bangladesh. SSRN Electronic Journal, 1-19.

Finlay, L. (2011). The social enterprise mark research agenda: A response. Presentation to the international social innovation research conference. September 11-12 $2^{\text {th }}$ London: London South Bank University.

Giddens A. (2000). The third way and its critics. Cambridge: Polity Press.

Wild, P.J., Giess, M. D. \& McMahon, C. A. (2009) Describing engineering documents with faceted approaches: Observations and reflections. Journal of Documentation, 65(3), 420-445.

Haugh, H. (2005). A research agenda for social entrepreneurship. Social Enterprise Journal, 1(1), 1-12.

Haugh, H. (2006). Community-led social venture creation. Entrepreneurship Theory and Practice, 31(2), 161-182.

Hieu, N. D. (2017). The organizational culture of social enterprises: A comparative study. Aalto Business School, Espoo: Aalto University.

Kerlin, J. A. (2009). Introduction. In: Kerlin, J. A. (eds.). Social enterprise: A global comparison (pp. 2-11). Hanover, NH: Tufts University Press. 
Mason, C. (2010). Choosing sides: Contrasting attitudes to governance in social firms in the United Kingdom. Social Enterprise Journal, 6(1), 6-22.

Merriam, S. B. (1988). Case study research in education: A qualitative approach. San Francisco, CA: Jossey-Bass.

McLoughlin, J., Kaminski, J., Sodagar, B., Khan, S., Harris, R., Arnaudo, G. and Brearty, S. Mc. (2009). A strategic approach to social impact measurement of social enterprises: The SIMPLE methodology. Social Enterprise Journal, 154-178.

Mogalakwe, M. (2006). The use of documentary research methods in social research. African Sociological Review, $10(1), 221-230$.

Mswaka, W. \& Aluko, O. (2015). Corporate governance practices and outcomes in social enterprises in the UK: A case study of South Yorkshire. International Journal of Public Sector Management, 28(1), 57-71.

Nicholls, A. (2006). Playing the field: A new approach to the meaning of social entrepreneurship. Social Enterprise Journal, 2(1), 1-5.

Nicholls, A. (2010). Institutionalizing social entrepreneurship in regulatory space: Reporting and disclosure by community interest companies. Accounting, Organizations and Society, 35, 394-415.

Nyssens, M. (2009). Western Europe. In: Kerlin, J. A. (eds.). Social enterprise. A global comparison (pp. 12-34). Lebanon, NH: University Press of New England.

Pearce, J. (2003). Social enterprise in anytown. London: Calouste Gulbenkian Foundation.

Peattie, K. \& Morley, A. (2008). Eight paradoxes of the social enterprise research agenda. Social Enterprise Journal, 4(2), 91-107.

PricewaterhouseCoopers (PwC), 2013. A survey of Northern Ireland's third sector and its potential to become more enterprise driven. The Department of Enterprise, Trade and Investment and the Department for Social Development. [Online] Available ht: https:/www.economyni.gov.uk/sites/default/files/publications/deti/deti-dsd-3rd-sector-final-report-july-2013-v1.pdf [Accessed $15^{\text {th }}$ January, 2019].

PricewaterhouseCoopers (PwC), 2018. Scotland's leadership in social enterprise. [Online] https://www.pwc.co.uk/who-we-are/regional-sites/scotland/insights/social-enterprise-guest-blog-socialenterprise-scotland.html [Accessed: $15^{\text {th }}$ December 2018].

Urban, B. \& Kujinga, L. (2017). The institutional environment and social entrepreneurship intentions. International Journal of Entrepreneurial Behavior \& Research, 23(4), 638-655.

Ridley-Duff, R. (2009). Co-operative social enterprises: Company rules, access to finance and management practice. Social Enterprise Journal, 5(1), 50-68.

Ridley-Duff, R. \& Bull, M. (2011). Understanding social enterprise: Theory and practice. London: Sage Publications Ltd.

Ridley-Duff, R. \& Bull, M. (2016). Understanding social enterprise: theory and practice. (2nd ed.). London: Sage Publications Ltd.

Ridley-Duff, R. \& Southcombe, C. (2012). The social enterprise mark: A critical review of its conceptual dimensions. Social Enterprise Journal, 8(3), 178-200.

Saebi, T., Foss, N.J. \& Linder, S. (2019). Social entrepreneurship research: past achievements and future promises. Journal of Management, 45(1), 70-95.

Salamon, L., Anheier, H., List, R., Toepler, S., Sokolowski, S., \& Associates. (2004). Global civil society: Dimensions of the nonprofit sector, Vol. 2. Bloomfield, CT: Kumarian Press.

Santos, F. (2012). A positive theory of social entrepreneurship. Journal of Business Ethics, 111, 335-351.

School for Social Entrepreneurs. (2018). About us. [Online] Available at: https://www.the-sse.org/about-schoolfor-social-entrepreneurs/ [Accessed: $12^{\text {th }}$ November, 2016].

Selloni, D. \& Corubolo, M. (2017). Design for social enterprises. Codesigning an organizational and cultural change. The Design Journal: An International Journal for All Aspects of Design, 20, 1-16.

Snaith, I. (2007) Recent reforms to corporate legal structures for social enterprise in the UK: Opportunity or confusion? Social Enterprise Journal, 3(1), 20-30.

Social Enterprise UK. (2015). Leading the world in social enterprise 2015. [Online] Available at: https://www.socialenterprise.org.uk/leading-the-world-in-social-enterprise-2015 [Accessed 21 ${ }^{\text {st }}$ October, 2018].

Social Enterprise UK. (2014). What is the history of social enterprise? [Online] Available at: https://www.socialenterprise.org.uk/faqs/what-is-the-history-of-social-enterprise [Accessed: $14^{\text {th }}$ October, 2015].

Social Enterprise UK. (2017). The future of business: State of social enterprise survey. [Online] Available at: https://www.socialenterprise.org.uk/Handlers/Download.ashx?IDMF=a1051b2c-21a4-461a-896caca6701cc441 [Accessed: $1^{\text {st }}$ December, 2018].

Social Enterprise UK. (2018). Social impact UK impact report 2017/18. [Online] Available at: https://www.socialenterprise.org.uk/social-enterprise-uk-impact-report-20172018 [Accessed $14^{\text {th }}$ December, 
2018].

Social Value Lab. (2017). Social enterprise in Scotland: Census 2017. [Online] Available at: http://www.socialvaluelab.org.uk/wp-content/uploads/2017/09/Census-2017-Main-Report.pdf [Accessed: $25^{\text {th }}$ March, 2019].

Spreckley, F. (1981). Social audit: A management tool for co-operative working. Workaid. Leeds: Beechwood College Ltd.

Stephan, U., Braidford, P., Folmer, E., Lomax, S. \& Hart, M. (2017) Social enterprise: Market trends 2017. Department for Digital, Culture, Media and Sport Department for Business, Energy and Industrial Strategy. [Online] Available

at: https://assets.publishing.service.gov.uk/government/uploads/system/uploads/attachment_data/file/644266/ MarketTrends2017report_final_sept2017.pdf [Accessed 25 ${ }^{\text {th }}$ February, 2019].

Strategem. Social enterprise Northern Ireland (2019) Re-balancing the Northern Ireland economy: 2019 social enterprise report.

[Online] https://www.socialenterpriseni.org/sites/default/files/library/Social\%20Enterprise\%20New\%20Report\%20 Booket\%20Verison.pdf [Accessed 10 $0^{\text {th }}$ May, 2019].

Teasdale, S. (2012). What's in a name? Making sense of social enterprise discourses. Public Policy and Administration, 27(2), 99-119.

The Institute for Social Entrepreneurs. (2008). Evolution of the social enterprise industry: A chronology of key events. Dallas, TX: The Institute for Social Entrepreneurs.

Third Sector. (2015). Analysis: The rise and rise of community interest companies. [Online] Available at: https://www.thirdsector.co.uk/analysis-rise-rise-community-interest-companies/governance/article/1348096 [Accessed: 20 ${ }^{\text {th }}$ December, 2018).

Yunus, M. (2007). Creating a world without poverty: Social business and the future of capitalism. New York, NY: Public Affairs. 